\title{
KEPEMIMPINAN PARA PEREMPUAN MUSLIM DARI KERAJAAN ACEH DARUSSALAM (1641-1699)
}

\author{
Dedeh Nur Hamidah \\ IAIN Syekh Nurjati Cirebon (jurnal.dedeh@gmail.com) \\ Aan Nurjanah \\ IAIN Syekh Nurjati Cirebon
}

\begin{abstract}
History of Acehnese women who fought heroically and patriotic; They are not only willing to fight in the battlefield, but also in political leadership, recorded that Aceh led by sultanah (women leaders) for 59 years. This long history proves that Acehnese women have been selfserving in various fields, both as low-level leaders up to the highest leaders in society. The courage and crookedness of Acehnese women is extraordinary, especially in defending the ideals of nationality and religion. Therefore, Aceh deserves to be called the emancipation pioneer.
\end{abstract}

Keywords: female leadership, the kingdom of Aceh Darussalam

\begin{abstract}
Abstrak
Sejarah perempuan Aceh yang berjuang dengan heroik dan patriotik; mereka bukan hanya rela berjuang dalam medan perang, namun juga dalam kepemimpinan politik, tercatat Aceh dipimpin oleh sultanah (sultan perempuan) selama 59 tahun. Sejarah panjang ini membuktikan bahwa perempuan Aceh telah mendarmabaktikan diri dalam berbagai bidang, baik sebagai pemimpin di tingkat rendah sampai dengan pemimpin tertinggi di masyarakat. Keberanian dan kesatriaan perempuan Aceh sungguh luar biasa, terlebih dalam mempertahankan cita-cita kebangsaan dan keagamaannya. Oleh karena itu, Aceh pantas disebut sebagai daerah pelopor emansipasi.
\end{abstract}

Kata Kunci: kepemimpinan perempuan, kerajaan Aceh Darussalam

\section{A. Pendahuluan}

Perempuan adalah kelompok manusia yang tertindas. Pernyataan ini adalah gambaran tentang pengalaman kelam sekaligus potret buram kondisi perempuan sepanjang sejarah. Dalam tradisi ketimuran pra-Islam misalnya, perempuan diserupakan dengan binatang buas, kotor, dan berbahaya. Mereka dianggap sebagai makhluk yang dapat mengancam perdamaian manusia setiap saat. Dalam bukunya yang berjudul Sahnameh, al-Firdausi mengatakan bahwa lebih baik membenamkan perempuan dan naga dalam perut bumi karena dunia akan lebih baik andaikata tersucikan dari keberadaan mereka. Penindasan terhadap mereka juga tergambar dalam ungkapan seorang penyair Arab:

Ketika seorang ayah melahirkan seorang anak perempuan, hendaklah ia memikirkan tiga hal, ummah yang akan memingitnya, suami yang akan mengekangnya dan memperbudaknya, serta kuburan yang akan menimpanya hidup-hidup. Dan sungguh yang terakhir inilah alternatif terbaik bagi seorang ayah untuk anak perempuannya. ${ }^{1}$

Dalam tradisi India, posisi perempuan juga tidak menggembirakan.

1 Ali Syariati, Fatiah Citra Muslim Sejati, (Yogyakarta: Shalahuddin Press, 1985), h. 39 
Bagi mereka suami adalah wakil mereka di bumi. Hal ini menandakan bahwa perempuan pasrah dan tunduk sepenuhnya pada suami. Ia harus bersimpuh di kaki suaminya ketika tertidur dan siap melayani kebutuhan seksnya sesuai yang diinginkan. Itulah gambaran perempuan yang tertindas di masa lampau. ${ }^{2}$ Namun, hal ini berbeda dengan kondisi para perempuan di Kerajaan Aceh Darussalam yang berhasil menduduki kekuasaan menjadi seorang Laksamana dan Sultanah. Para Sultanah berhasil memimpin Kerajaan selama 59 tahun. Itulah bukti bahwa di Kerajaan Aceh Darussalam, perempuan bebas untuk mengembangkan karirnya.

Kerajaan Aceh Darussalam menjadikan Islam sebagai Dasar Negara dengan sumber hukumnya yaitu AlQuran dan Hadis. Hal tersebut tercantum dalam Qanun (Undang-undang Kerajaan Aceh Darussalam) yang telah ditetapkan oleh Sultan Iskandar Muda. Karena Islam telah diambil menjadi Dasar Negara, dan Al-Quran dan Hadis telah dinyatakan sebagai sumber hukum, maka kedudukan perempuan disesuaikan dengan ketentuan-ketentuan yang

2 Ibnu Musthafa, Perempuan Islam Menjelang Tahun 2000, (Bandung: Al-Bayan, 1993), h. 60 terdapat di dalamnya. ${ }^{3}$ Al-Quran telah menegaskan bahwa manusia diciptakan dari sumber yang satu, yaitu dari Adam, laki-laki maupun perempuan, dan berkulit putih maupun hitam. Kedudukan laki-laki dan perempuan sama, manusia sama derajatnya dalam pandangan Allah sebagaimana firman Allah surat An-Nisa ayat 1 .

Betapa besar juga perhatian Allah kepada perempuan, antara lain terbukti bahwa dalam Al-Quran terdapat sebuah surat yang bernama Surat an-Nisa (surat perempuan) yang isinya bersangkutan dengan masalah-masalah perempuan dalam masyarakat. Mengenai hak-hak perempuan untuk memegang jabatan dalam negara, hak jabatan yang tertinggi dinyatakan boleh asal mereka sanggup dan mempunyai pengetahuan untuk bidang-bidang jabatan yang akan dipegangnya. Dalam masalah jihad atau perang, dalam masalah negara, menurut Islam kewajiban laki-laki dan perempuan sama, artinya sama-sama wajib berjihad untuk menegakkan agama Allah, sama-sama wajib berjihad untuk membela tanah air, sama-sama wajib bekerja untuk memimpin dan membangun Negara, seperti yang dipahami hadis berikut.

\footnotetext{
3 A. Hasjmy, 59 Tahun Aceh Di Bawah Pemerintahan Ratu, (Jakarta: Bulan Bintang,
} 1977), h. 21-22 
Diriwayatkan Imam Bukhari dari seorang sahabat perempuan, yang mengatakan: Kami pergi berperang bersama Rasulullah, antara lain tugas kami menyediakan makan dan minum bagi para prajurit dan mengembalikan anggota tentara yang syahid ke Madinah (HR. Bukhari $)^{4}$

Berdasarkan dalil Al-Quran dan Hadis serta pendapat para ulama, maka Kerajaan Islam Perlak, Kerajaan Islam Samudera Pasai, dan Kerajaan Aceh Darussalam telah memberikan persamaan kewajiban dan hak antara perempuan dan laki-laki. Karena itu, suatu hal yang logis jika sejarah mencatat nama perempuan yang telah memainkan peranan yang sangat penting di tanah Aceh sejak jaman Kerajaan Islam Perlak sampai Kerajaan Aceh Darussalam.

Di tanah Aceh, tercatat beberapa perempuan yang memegang tampuk kekuasaan tertinggi kerajaan. Meski mereka perempuan, nyatanya mereka bisa mengelola Aceh Darussalam sebagaimana yang dilakukan oleh para lelaki pendahulunya.

\section{B. Latar Belakang Kepemimpinan Perempuan di Kerajaan Aceh Darussalam}

\section{Kondisi Politik}

Kepemimpinan para Sultanah disebabkan karena Sultan Iskandar Muda

${ }^{4} I b i d .$, h. 23 wafat 27 Desember 1636. Sumber Barat mengatakan bahwa lima belas hari sebelum wafat, sultan telah menghukum mati puteranya sendiri karena sang putera telah berkelakuan jahat dan tidak dapat dikendalikan. Karena Sultan Iskandar Muda takut keselamatan Aceh di kemudian hari terancam, maka atas dasar beberapa kesalahannya yang tidak dapat dimaafkan lagi, puteranya itu dihukum mati. Putera sultan telah tertangkap basah ketika menzinahi istri orang.

Pada suatu hari terdapat orang tua yang ia telah mendapat izin masuk ke istana untuk melaporkan langsung pada Sultan, bahwa anak perempuannya telah dibunuh oleh menantunya karena ketahuan berselingkuh. Ia melapor pada Sultan sambil menyatakan pendapatnya sesuai dengan Hukum Islam, bahwa kedua orang yang berzina harus sama-sama dibunuh. Ia mengatakan bahwa si menantu hanya membunuh istrinya, si laki-laki tidak. Karena laki-laki itu justru putera Sultan sendiri (putera mahkota), mungkin itu sebab menantunya tidak berani membunuh laki-laki itu. Laporan tersebut diterima Sultan dan setelah dilakukan penyelidikan ternyata benar, lalu Sultan memutuskan menghukum mati (rajam) puteranya itu. ${ }^{5}$

Isteri kedua yaitu Puteri Rani, Puteri dari Daeng Mansyur ${ }^{6}$, berasal dari keluarga Raja-raja Bugis, sehingga jika puterinya itu beranak laki-laki, maka berhak jugalah ia diangkat menjadi

\footnotetext{
${ }^{5}$ Muhammad Said, Aceh Sepanjang Abad, (Medan: Waspada, 1981), h. 332

${ }^{6}$ Daeng Mansyur adalah ulama yang disebut Syekh Daim bin Syekh Abdullah bergelar "Kadhi Malikul Adil" yang menjabat pangkat Kadi Besar Kerajaan Aceh Darussalam
} 
sultan menggantikan ayahnya. Namun ternyata, anaknya hanya perempuan bernama Puteri Shafia yang bersuami Sultan dari Kerajaan Pahang yaitu Sultan Iskandar Thani. Istri ketiga yaitu gundik (budak) yang berasal dari Habsyi. Sultan memperoleh anak laki-laki yang digelari orang Imam Hitam atau Tengku di Batue Timoh. Menurut adat Melayu, ia tidak berhak menjadi sultan karena anak budak, padahal ia anak laki-laki Sultan yang sangat dikasihi karena kecerdasan, keahlian, dan kegagahannya sehingga diberi gelar Panglima Polem Muda Sakti. $^{7}$

Setelah Sultan Iskandar Muda melakukan hukuman rajam terhadap puteranya, yang akan menggantikannya sebagai Sultan Aceh, maka tidak ada lagi di antara putera-puteranya yang berhak menjadi sultan, karena mereka bukan anak dari permaisuri. Oleh karena itu, sebelum Iskandar Muda wafat pada 1636 $\mathrm{M}$ ia telah menunjuk menantunya, Sultan Iskandar Thani ${ }^{8}$ sebagai putera mahkota yang akan menggantikannya, dengan

\footnotetext{
7 Hamka, Ummat Islam, (Jakarta: Bulan Bintang, 1961), h. 367

${ }^{8}$ Sultan Iskandar Thani adalah putera dari Sultan Ahmad dari Pahang yang dibawa oleh Sultan Iskandar Muda ke Aceh, pada saat ia ke Perak untuk membersihkan negeri itu dari pengaruh Portugis, karena kecakapan dan kemuliaan budi Iskandar Thani, maka Sultan Iskandar Muda mengangkatnya menjadi menantu, dipersuamikan dengan anaknya yang bernama Puteri Shafia. Lihat A. Hasjmy, Op.Cit., h. 48
}

persetujuan dari Kadhi Malikul Adil dan anggota-anggota Balai Gading. ${ }^{9}$ Karena Panglima Polem merupakan keturunan budak, maka ia tidak berhak menggantikan ayahnya, namun ia diberi kekuasaan di Sagi XXII Mukim. Maka yang menggantikannya adalah menantunya yang bernama Sultan Iskandar Thani (1636-1641), anak dari Kerajaan Pahang. Setelah Iskandar Thani wafat pada 1641 M maka yang menggantikan adalah isterinya, Puteri Shafia, yang dijadikan Sultanah pertama di Kerajaan Aceh Darussalam yang bergelar Sultanah Sri Ratu Tajul Alam Shafiatuddin Johan Berdaulat (16411675). ${ }^{10}$

\section{Kondisi ekonomi}

Pada masa Sultan al-Mukammil dan Malahayati menjabat sebagai Laksamana kegiatan perdaganga awalnya tidak stabil karena Portugis sering menyerang Kerajaan Aceh Darussalam. Namun setelah mengadakan perdamaian dengan Portugis, kondisi ekonomi Kerajaan menjadi stabil karena perdagangan dari hasil-hasil bumi, terutama lada, dapat ditingkatkan.

Pada masa Sultan Iskandar Thani (1636-1641), beberapa kerajaan di

\footnotetext{
${ }^{9}$ Ibid.

${ }^{10}$ Hamka, Op. Cit., h. 368
} 
Semenanjung Melayu sudah tidak lagi berada di bawah pengaruh Kerajaan Aceh Darussalam. Seperti Kerajaan Johor yang sudah memisahkan diri dari pengawasan Aceh dan telah mengadakan suatu perjanjian persekutuan dengan pihak Belanda. Kerajaan Pahang juga sudah bebas dari pengontrolan pihak Aceh, tetapi antara Kerajaan ini dengan Kerajaan Aceh masih terjalin hubungan baik, karena Sultan Iskandar Thani yang menjadi Sultan Aceh adalah bekas putera mahkota Kerajaan Pahang. Satu-satunya yang masih berada di Kerajaan Aceh adalah Kerajaan Perak. Maka, untuk menghindari banyaknya pemisahan kerajaan-kerajaan yang telah ditaklukkan sebelumnya oleh Iskandar Muda, maka setelah wafatnya Iskandar Thani, diangkatlah Puteri Shafia untuk mengatasi hal tersebut. Dan setelah Puteri Shafia menjadi Sultanah kondisi ekonomi menjadi lebih stabil karena para pedagang asing yang ingin membeli timah harus memperoleh izin darinya. ${ }^{11}$

\section{Kondisi Agama}

Kerajaan Aceh Darussalam merupakan kerajaan Islam yang menjadikan Al-Quran dan Hadis sebagai sumber hukumnya. Dan sesuai ajaran Islam, maka Kerajaan Aceh Darussalam

\footnotetext{
${ }^{11}$ Ibid, h. 76
}

memberikan kedudukan yang sama antara laki-laki dan perempuan. Sehingga di Kerajaan Aceh Darussalam banyak muncul tokoh perempuan yang memimpin pemerintahan seperti para Sultanah maupun sebagai pahlawan dalam peperangan seperti Laksamana. Dengan jabatan tersebut, mereka (para pemimpin perempuan) memiliki kewajiban terhadap kerajaan, seperti kewajiban untuk membela dan memajukan kerajaan, oleh karena itu perempuan di pandang sama dengan laki-laki dalam Hukum Kerajaan. ${ }^{12}$ Putri Shafia juga mendapat dukungan dari ulama yang bernama al-Raniri karena sikapnya yang tegas dalam menyatakan hukum. Putri Shafiah tidak keberatan ketika Syekh Nuruddin bermusyawarah dengan para pembesar kerajaan menyatakan bahwa dalam agama Islam tidak ada larangan yang tegas melarang perempuan memimpin pemerintahan. Menurutnya cuma satu hal yang tidak boleh di pegang oleh perempuan yaitu seorang hakim. ${ }^{13}$

\section{Kepemimpinan Para Perempuan Muslim Dari Kerajaan Aceh Darussalam}

\footnotetext{
${ }^{12}$ Emi Suhaemi, Wanita Aceh Dalam Pemerintahan Dan Peperangan, (Banda Aceh: CV. Gua Hira, 1993), h. 3-4

${ }^{13}$ Hamka, Op. Cit.,h. 371
} 


\section{Sultanah Sri Ratu Tajul Alam Safiatuddin Syah Memerintah pada 1641-1675 M}

Sultan Iskandar Thani wafat pada 15 Februari 1641, dalam usia 31 tahun. Setelah wafat, ia terkenal dengan nama Marhum Darussalam. Akhirnya setelah tiga hari wafatnya Sultan Iskandar Thani, ${ }^{14}$ atas putusan pembesar negara dan para ulama di bawah pimpinan Kadhi Malikul Adil, Syekh Nuruddin alRaniri, mengadakan musyawarah untuk membicarakan siapa yang berhak dinobatkan menjadi Sultan di Kerajaan Aceh Darussala. Setelah musyawarah yang lama, maka diperoleh keputusan bahwa Permaisuri lskandar Thani, Puteri Shafia, diangkat menjadi Sultanah. Hal ini terjadi setelah para ulama menegaskan hukum bahwa boleh seorang wanita menjadi raja asal memenuhi syarat-syarat keagamaan, akhlak, dan ilmu pengetahuan. ${ }^{15}$ Karena sikapnya yang tegas dalam menyatakan hukum, Pueri Shafia tidak keberatan ketika Syekh Nururddin menyatakan bahwa dalam agama Islam tidak ada larangan yang tegas tentang kepemimpinan perempuan. Menurut Syekh Nuruddin cuma satu hal yang

${ }^{14}$ Raden Hoesein Djajadiningrat, Kesultanan Aceh, (Daerah Istimewa Aceh: Departemen Pendidikan dan Kebudayaan, 1982/1983), h. 56

${ }^{15}$ A. Hasjmy, Op. Cit., h. 49 tidak boleh dipegang oleh sultan perempuan yaitu seorang hakim sehingga dinobatkanlah Puteri Shafia menjadi Sultanah dengan gelar Sultanah Sri Ratu Tajul Alam Shafiatuddin. ${ }^{16}$ Pelantikannya menjadi seorang sultanah tidaklah menggembirakan hati Puteri Shafia karena yang digantikannya adalah suami yang sangat dicintainya yang berarti bahwa ia harus menjadi janda pada usia yang muda. Oleh sebab itu, tahun 1641 merupakan tahun kesedihan baginya karena suaminya yang tercinta pergi untuk selamanya tanpa meninggalkan keturunan. Kecintaan Puteri Shafia kepada suaminya sangat mendalam, terbukti setelah ia dilantik menjadi sultanah, hal pertama yang ia lakukan, yaitu membuat kandang (makam) bagi suaminya itu lebih indah dari kandang-kandang yang telah ada. ${ }^{17}$

\section{a. Tegas Memberikan Hukuman}

Seorang warga divonis mati oleh Kadli Malikul Adil (ar-Raniry) dan dewan hakim lainnya dalam kasus pembunuhan. Terdakwa mengajukan petisi untuk membayar 388 tahil sebagai ganti vonis mati. Kadli kemudian membawa kasus ini kepada Sultanah Shafiatuddin. Sultanah tidak memberikan keputusan, tetapi ia

\footnotetext{
${ }^{16}$ Hamka, Op. Cit., h. 371

${ }^{17}$ A. Hasjmy, Op. Cit., h. 87
} 
memerintahkan supaya kasus besar tersebut diselesaikan baik menurut kebiasaan yang berlaku (Hukum Adat) maupun hukum yang dianut (Hukum Islam). Selanjutnya, petisi yang diajukan oleh terdakwa untuk membayar sejumlah uang dapat dimaknai sebagai diyyah yang diberikan kepada ahli waris korban.

Menurut ketentuan yang sesuai dengan Hukum Islam yang juga terdapat di dalam Adat Meukuta Alam karya Sultan Iskandar Muda, pada ayat 25, 26, 27, 28 dan 29 mengenai hukum qisas dan diyyah, diputuskan hukuman mati terhadap pelakunya dalam kasus ini. ${ }^{18}$

Sejak masa Sultan Iskandar Muda, mengkonsumsi arak dan tuak merupakan sebuah larangan keras karena arak dan tuak termasuk minuman yang memabukkan dan dilarang keras dalam Islam. Memproduksi dan memperdagangkannya di Aceh berada di bawah pengawasan ketat Kerajaan dan hukuman berat diberikan kepada yang melanggarnya. Di Aceh saat itu, hanya pedagang asing non-muslim yang diberikan izin resmi untuk mengkonsumsi arak. Berbagai aturan yang ketat diterapkan dalam memproduksi dan menjual minuman keras. Jacob Compostel menginformasikan, bahwa seorang bernama nakhoda Fijgie telah diberikan izin untuk memproduksi arak. Namun, pada tahun 1642 dua orang pekerja Eropa pada sebuah pabrik milik perusahaan lnggris ini dihukum oleh Shafiyatuddin dengan memotong kedua tangan mereka karena telah berusaha memproduksi arak yang sebenarnya dilarang oleh Sultanah. Meskipun orang orang Eropa telah diberikan izin untuk mengkonsumsi arak, namun mereka dilarang keras meminumnya di rumah masyarakat Aceh. Dalam laporan Compostel, diinformasikan bahwa dua orang Aceh ditemukan sedang mabuk di rumah nakhoda Fijgie. Kemudian mereka ditangkap dan dihukum oleh penghulu kawal (kepala polisi) dengan menuangkan timah panas ke kerongkongan mereka. Hukuman yang diberikan kepada masyarakat Aceh didasarkan pada Hukum Adat bukan atas ketentuan yang diberikan dalam Hukum lslam. $^{19}$

\section{b. Perkembangan Ilmu Pengetahuan Di Zaman Shafiatuddin}

Sejak berusia tujuh tahun, Ratu Shafiatuddin telah belajar bersama-sama dengan lskandar Thani dan putera Istana lainnya pada para ulama besar yang

${ }^{19}$ Ibid., h. 256-257 
terkenal seperti Syekh Hamzah Fansury, Syekh Nuruddin Ar-Raniry, Sri Faqih Zainul Abidin lbnu Daim Mansur, Syekh Kamaluddin, Syekh Alaiddin Ahmad, Syekh Muhyiddin Ali, Syekh Taqiuddin Hasan, Syekh Saifuddin Abdulkahhar dan lain-lain (semuanya Guru Besar pada Jami Baiturrahman). Selesai pendidikannya, Shafiatuddin telah menguasai berbagai macam Bahasa seperti Bahasa Arab, Persia, Spanyol dan Urdu. Bahkan ia juga menguasai berbagai ilmu pengetahuan seperti ilmu fiqih (Hukum Islam) termasuk hukum tata-negara, ilmu sejarah, manthik, falsafah tasauwuf, sastra dan lain-lain. ${ }^{20}$

Jami' Baiturrahman (Universitas Baiturrahman) di Bandar Aceh bertambah maju, demikian pula pusatpusat pendidikan (dayah-dayah) di seluruh Aceh, bahkan di segenap penjuru daerah atau wilayah yang berada dalam lingkungan Kerajaan Aceh Darussalam, seperti di Ulakan Sumatera Barat, Kedah, Siak Seri Indrapura dan sebagainya. Kira-kira tiga ratus orang Ulama yang tidak menyetujui politik Sultanah Shafiatuddin dalam menjalankan pemerintahan dibiarkan menyebarkan diri ke seluruh wilayah Kerajaan untuk mendirikan pusat-pusat pendidikan, seperti Syekh Abdul Wahab

\footnotetext{
${ }^{20}$ A. Hasjmy, Op. Cit, h. 95
}

yang hijrah ke Tiro dan mendirikan Pusat Pendidikan Islam di sana sehingga di sana menjadi salah satu pusat pendidikan yang terkenal di Kerajaan Aceh Darussalam. Sultanah Shafiatuddin juga tidak menangkap dan menahan para ulama yang menentang kebijaksanaan politiknya karena ia adalah seorang yang berpaham demokrasi yang sangat mencintai ilmu pengetahuan. Pada hakikatnya, ia tidak akan mengambil tindakan keras terhadap "para syekh wujudiyah" dan para pengikutnya, jika mereka tidak melakukan tindak-pidana yang merupakan sabotase, subversif, pembakaran, pembunuhan dan sebagainya. $^{21}$

Sultanah Shafiatuddin mendapat gelar Ratu Kesusastraan karena pada masa pemerintahannya merupakan zaman emas ilmu pengetahuan di Kerajaan Aceh Darussalam. Ratu dikenal gemar membaca sajak, terutama hasil karya-karya sastra dalam Bahasa Melayu dan Bahasa Arab. ${ }^{22}$ Banyak ulama besar seperti Syekh Nuruddin Ar-Raniry, Syekh Abdurrauf, Syekh Daud atau Teungku Chik Dileupeu Baba Daud, dan lain-lain. Sultanah Shafiatuddin mendorong para ulama dan sarjana untuk mengarang buku-buku dalam berbagai

${ }^{21}$ Ibid., h. 98

${ }^{22}$ Ibid., h. 158 
disiplin ilmu. Pada mukaddimah bukubuku tersebut disebutkan bahwa buku itu dikarang atas anjuran Sultanah Shafiatuddin, seperti buku Hidayatul Iman fi Fadhil Manan karya Syekh Nuruddin Ar-Raniry dan buku Miratuth Thullab karya Abdurrauf Syiah Kuala. ${ }^{23}$

Masa pemerintahan Sultanah Shafiatuddin selama 34 tahun, satu masa yang cukup panjang, terutama bagi seorang perempuan yang memimpin sebuah kerajaan. Masa pemerintahannya penuh dengan permasalahan agama yang berujung pada pengkhianatan para tokoh yang ingin merebut kursi kedudukannya. Maka, masa 34 tahun itu adalah masa yang tidak akan dapat dilampaui dengan selamat tanpa kebijaksanaan dan keluarbiasaan yang dimiliki Sultanah Tajul Alam Shafiatuddin.

\section{Sultanah Sri Ratu Nurul Alam Naqiatuddin Memerintah 1675 - $1678 \mathrm{M}$.}

Semasih hidupnya, Sultanah Shafiatuddin telah mempersiapkan tiga wanita untuk dijjadikan penggantinya, salah satunya bernama Puteri Naqiah. Sesuai ketentuan dalam Kanun Al-Asyi atau Adat Meukuta Alam, maka sebelum Sultanah Shafiatuddin dimakamkan, dilantiklah Puteri Naqiah menjadi

\footnotetext{
${ }^{23}$ Emi Suhaimi, Op. Cit., h. 14
}

Sultanah Kerajaan Aceh Darussalam pada 23 Oktober $1675 \mathrm{M}$ dengan gelar Sultanah Sri Ratu Nurul Alam Naqiatuddin. Ia memerintah sampai tahun 1678 M. Sejak awal memerintah, Sultanah Naqiatuddin telah menghadapi tantangan-tantangan yang besar, baik dari dalam maupun dari luar negeri. Ancaman terhadap Kerajaan Aceh Darussalam bertambah hebat dari Barat (Belanda, Portugis, Inggris) yang membawa Agama Kristen, sementara di dalam negeri "kaum Wujudiyah" yang telah menyimpang dari ajaran Islam, berusaha meningkatkan perlawanannya terhadap Sultanah Naqiatuddin. Kaum wajudiyah dimanfaatkan oleh golongan tertentu yang ingin menduduki kursi kesultanan. Mereka melakukan sabotase dengan melakukan pembakaran kota Banda Aceh yaitu membakar Masjid Raya Baiturrahman dan Istana Seri Sulthan sehingga segala isinya habis musnah dimakan api. Kebakaran di Aceh yang maha dahsyat itu turut menggemparkan Malaka, yang memuat peristiwa itu dalam catatan kerajaan pada tahun $1677 \mathrm{M}^{24}$

Untuk menghadapi rongrongan dalam negeri yang semakin terasa, Sultanah berusaha memperkuat kedudukannya atau lebih umum lagi 
kedudukan Pemerintah Pusat, antara lain dengan mengadakan perubahanperubahan dalam beberapa pasal Kanun Meukuta Alam (Undang-undang Dasar Kerajaan). Di antara perubahanperubahan penting yang dilakukan Sultanah Nurul Alam Naqiatuddin, dengan petunjuk Kadli Maikul Adil, Syekh Abdurrauf Syiah Kuala dan dengan persetujuan Balai Mahkamah Rakyat, yaitu mengenai pembentukan Federasi Tiga Sagi Aceh Rayek (Aceh Besar). Yang masing-masing dikepalai oleh seorang Panglima Sagi, yaitu Sagi XXII Mukim, Sagi XXV Mukim dan Sagi XXVI Mukim. ${ }^{25}$ Kedudukan ketiga orang Panglima Sagi sangat kuat, antara lain yang memberi kata akhir dalam pengangkatan atau pemberhentian seseorang Sulthan, seperti dinyatakan dalam Kanun Meukuta Alam yang telah disempurnakan itu, yang ikhtisarnya yaitu:

1. Yang berhak memilih dan memakzulkan Sultan, yaitu:
a. Seri Imeum Muda Panglima Cut Oh, Panglima XXVI Mukim.
b. Seri Setia Ulama, Panglima XXV Mukim. c. Seri Muda Perkasa

\footnotetext{
${ }^{25}$ A. Hasjmy, Op. Cit., h. 189
}

Panglima Polem,

Panglima XXII Mukim.

d. Kadli Malikul Adil, Mufti Besar Kerajaan.

2. Seorang Sultan yang akan diangkat berkewajiban membayar:
a. 32 kati emas murni
b. 16.000 ringgit.

3. Seorang Sultan baru boleh dan sah dinobatkan, setelah nyata Sultan sebelumnya wafat.

4. Daerah-daerah yang langsung di bawah perintah Sultan, yaitu:

a. Daerah Keraton DarudDunia dan Ibukota Bandar Aceh Darussalam.

b. Mukim Masjid Raya.

c. Mukim Lung Bata.

d. Mukim Pagar Aye.

e. Mukim Lamsayun.

f. Kampung Pandee.

g. Kampung Jawa.

h. Kampung Pelanggahan.

i. Mukim Meraksa.

5. Kepala-kepala Pemerintahan (Uleebalang, para Menteri dan sebagainya) di luar Aceh Rayek, diangkat oleh Sultan menurut gelarnya masingmasing, dengan dibubuhi Cap Sikureung (Setempel Halilintar). 
6. Kepala-kepala Pemerintahan Dalam Aceh Rayek, diadakan dengan turun-temurun, tanpa ada pengangkatan baru.

7. Hak otonomi diberi seluasluasnya kepada semua Pemerintah Daerah, termasuk keuangan, kecuali beberapa macam sumber kekayaan yang langsung dikuasai Sultan.

8. Urusan luar negeri dan pertahanan, semuanya dalam urusan pemerintah pusat (Sultan). ${ }^{26}$

Kaum wujudiyah berusaha untuk menjatuhkan Sultanah Naqiatuddin dengan cara hukum tidak berhasil, karena ketiga Panglima Sagi dan Kadli Malikul Adil tetap mempertahankan, teristimewa karena sebagian besar para ulama menyatakan sah perempuan menjadi Kepala Negara. Karena itu, kaum wujudiyah yang diperalat golongan politik tertentu melakukan kampanye gelap bahwa menurut hukum Islam, perempuan tidak boleh menjadi Kepala Negara, mereka juga melakukan pelanggaran hukum serta tata tertib. Demikianlah, setelah setahun Sultanah Naqiatuddin memerintah, maka kaum wujudiyah berhasil membakar ibukota Bandar Aceh Darussalam sehingga

${ }^{26}$ Ibid., h. 189-190
Masjid Jami' Baiturrahman dan Keraton Darud Dunia terbakar habis serta sebagian besar ibukota Bandar Aceh Darussalam. Perbuatan kaum wujudiyah tersebut telah melumpuhkan pemerintahan Sultanah Nurul Alam Naqiatuddin, sehingga segala rencana yang telah dibuatnya menjadi berantakan. ${ }^{27}$ Hal tersebut tercatat dalam sebuah catatan orang Belanda yang menyatakan bahwa Sultanah Naqiatuddin sangat menderita akibat kebakaran besar yang memusnahkan segalanya, istananya dan masjidnya. Setelah memerintah selama dua tahun, pada 23 Januari 1678 Sultanah Naqiatuddin wafat. $^{28}$

\section{Sultanah Sri Ratu Zakiatuddin Inayat Syah Memerintah 1678- $1688 \mathrm{M}$.}

Sultanah Naqiatuddin wafat pada 23 Januari 1678, sebelum pemakamannya terlebih dahulu dinobatkan Puteri Zakia menjadi Sultanah Kerajaan Aceh Darussalam dengan gelar Sultanah Sri Ratu Zakiatuddin Inayat Syah, yang memerintah sampai tahun 1688. Puteri Zakia adalah calon pengganti kedua

\footnotetext{
${ }^{27}$ Ibid., h. 191-192

${ }^{28}$ Mohammad Said, Op. Cit., h. 407-408
} 
yang dipersiapkan oleh Sultanah

Shafiatuddin untuk memimpin Kerajaan Aceh Darussalam. Karena Sultanah Shafiatuddin telah mempersiapkan tiga orang puteri yang akan menggantikannya sebagai sultanah di Kerajaan Aceh Darussalam. Mereka yang dipersiapkan itu telah dididik dalam istana Darud Dunia dengan berbagai ilmu pengetahuan: ilmu hukum termasuk hukum tata-negara, sejarah, filsafat, kesusastraan, pengetahuan agama Islam, Bahasa Arab, Bahasa Persia, Bahasa Spanyol, dan Bahasa Inggris. Itulah kebijaksanaan dan kearifan Sultanah Shafiatuddin yang telah mempersiapkan para penggantinya dengan berbagai ilmu, ia juga telah membuktikan bahwa perempuan juga sanggup memerintah jika dididik dan diberi kesempatan. Karena hal itulah maka pengangkatan para sultanah setelahnya tidak mengalami kesulitan dan mereka tidak merasa bingung setelah dinobatkan menjadi sultanah. Selain itu, hal lain yang menguntungkan, yaitu Syekh Abdurrauf Syiah Kuala tetap menjadi Kadli Malikul Adil setelah wafat Sultanah Shafiatuddin sampai kepada masa pemerintahan Sultanah Kamalat Syah. $^{29}$
Begitu naik tahta, Sultanah Zakiatuddin juga menghadapi tantangan yang lebih berat dari para sultanah sebelumnya. Hanya karena pengaruh yang besar dari Kadli Malikul Adil, Syekh Abdurrauf Syiah Kuala, tantangan-tantangan itu dapat diatasinya. Kebijaksanaan politik para sultanah sebelumnya terhadap VOC maupun terhadap rongrongan kaum wujudiyah pun diteruskannya. Sikap tegas demikian itu mendapat sambutan baik dari masyarakat Minangkabau, sehingga menimbulkan kesulitan bagi perwakilan VOC di Padang yang harus menghadapi peperangan yang hebat selama dua tahun dengan rakyat di sana. ${ }^{30}$

Sultanah Zakiatuddin melakukan berbagai macam usaha untuk mematahkan kekuatan Persatuan Dagang Belanda itu untuk kepentingan dan keselamatan rakyatnya. Dengan semua negara tetangga diikatnya perjanjian persahabatan dan perjanjian saling bantu untuk melumpuhkan kekuasaan Belanda. Di samping menghadapi segala tantangan, dengan tegas Sultanah Zakiatuddin bertindak cepat untuk memajukan pendidikan dan ilmu pengetahuan. Dayah-dayah yang telah ada terus dipelihara selain mendirikan yang baru, sementara Pusat Pendidikan

\footnotetext{
${ }^{30}$ Emi Suhaimi, Op. Cit., h. 18-19
} 
Tinggi

Baiturrahman

terus

dikembangkan di bawah pimpinan

Syekh Abdurrauf Syiah Kuala dan para ulama lainnya. Meunasah dan Masjid dibina dan ditingkatkan fungsinya sehingga ajaran Agama Islam merata ke dalam jiwa para rakyat. ${ }^{31}$

Masa pemerintahan Sultanah Zakiatuddin Inayat Syah tidak diketahui banyak, tetapi ada catatan tentang kedatangan utusan dari luar negeri sebanyak dua kali yaitu utusan Syarif Mekkah dan utusan Inggris. Mengenai utusan Syarif Mekkah, menurut Dr. Snouck Hurgronje pada masa Syarif Sai'id memerintah (1682-1684), ayahnya, Syarif Barakat, sebagai penguasa Mekkah dan Madinah mengirim bingkisan kepada Sultan India (Sultan Mughal Akbar Aurangzeb), yang menjadi pimpinan para utusan pembawa bingkisan itu adalah El-Hajj Jusuf al-Qudsi. Sultan (India) itu tidak ingin menerimanya, tidak pula tertarik untuk mengetahui bingkisan yang dibawanya. Oleh karena itu, utusan memutuskan untuk berangkat ke Aceh pada 1683 . Negeri ini sedang diperintah oleh seorang perempuan. Setibanya di Aceh, dipersembahkan bingkisan tersebut sambal menjelaskan bahwa bingkisan itu adalah kiriman Syarif Barakat, penguasa

${ }^{31}$ A. Hasjmy Op. it., 201
Mekkah dan Madinah. Sultanah sangat gembira menerimanya, maka tidaklah sia-sia apa yang disampaikannya. Bahkan, Sultanah menyarankan supaya mereka tinggal di Aceh, sebab ia ingin mengirim bingkisan balasan dan untuk menyiapkannya perlu waktu. ${ }^{32}$

Tanah Aceh yang juga telah dikenal oleh utusan Syarif Mekkah sebagai satu Kerajaan yang taat kepada peraturan-peraturan Agama Islam. Utusan itu diterima Sultanah dengan segala upacara kebesaran sehingga menimbulkan perasaan puas pada mereka. Utusan Syarif Mekkah ingin menyaksikan apakah benar laporan kaum wujudiyah yang menyatakan bahwa Kerajaan Aceh Darussalam di bawah pemerintahan Sultanah telah jauh menyimpang dari Agama Islam. Dalam peninjauan para utusan itu, Kerajaan Aceh Darussalam adalah benar-benar Kerajaan Islam yang Ahlus Sunnah wal Jama'ah dan bermazhab Syafi'i. Mereka sangat kagum menyaksikan Kerajaan Aceh Darussalam yang cantik dan permai, berbagai suku bangsa tinggal di sana dan kebanyakan dari mereka merupakan para saudagar. Ketika mendapat kesempatan menghadap sultanah, mereka menyaksikan sultanah dan para pembantunya yang terdiri dari

\footnotetext{
${ }^{32}$ Muhammad Said, Op. Cit., h. 410
} 
para perempuan duduk di balik tabir kain sutera dewanga yang berwarna kuning berumbai-rumbai dan berhiaskan emas permata. Sultanah berbicara dalam Bahasa Arab yang fasih dengan menggunakan kata-kata yang diplomatis, sehingga menimbulkan kekaguman para utusan Syarif Mekkah. Keheranan semakin bertambah ketika mereka menyaksikan tentara pengawal istana yang terdiri dari para prajurit perempuan yang semuanya mengendarai kuda. Bahkan pakaian kuda-kuda itu dari emas, suasa dan perak. Tingkah laku pasukan kehormatan dan pakaian mereka pun cukup sopan, tidak ada yang menyalahi aturan Agama Islam. Mereka dapat menyaksikan sisa-sisa kebesaran istana dan Masjid Baiturrahim, yang pada masa pemerintahan Sultanah Naqiatuddin dibakar oleh kaum wujudiyah. Setahun lamanya mereka menjadi tamu di Kerajaan Aceh Darussalam. Waktu mereka akan pulang, Sultanah Zakiatuddin menghadiahkan kepada mereka berbagai rupa benda yang bernilai, di samping menitipkan hadiah kepada Syarif Mekkah, Masjidil haram dan kepada masjid Nabawi di Madinah. Hadiah-hadiah tersebut terdiri dari:

1. Tiga kinthar emas murni.

2. Tiga rithal kamfer (kapur barus) dan kayu cendana.

3. Tiga gulyun (alat pengisap tembakau) dari emas.

4. Dua penyondong (lampu kaki) dari emas.

5. Lima lampu gantung dari emas.

6. Lampu kaki dan kandil dari emas, dan lain-lain.

Dalam rombongan Syarif yang datang ke Aceh itu, ada dua orang Syarif bersaudara, yaitu Syarif Hasyim Jamalullail dan Syarif Ibrahim. Selama rombongan mereka berada di Aceh, telah menarik perhatian beberapa orang pembesar yang dalam hatinya yang memang anti kepada Raja Perempuan. Dalam menjalankan rencananya meniadakan Dinasti Sultanah, mereka melihat dua Syarif bersaudara yang ambisius dapat diajak kerjasama. Karena itu, mereka mengusulkan kepada Ketua Utusan agar Syarif Hasyim dan Syarif Ibrahim dapat tinggal di Aceh untuk membantu pengembangan ajaran-ajaran Islam. Permintaan pun dikabulkan, teristimewa karena dua Syarif bersaudara itu telah menyetujuinya karena mereka telah lebih dahulu dipengaruhi berbagai macam janji, antara lain, jika Sultanah dapat dijatuhkan salah seorang di antara mereka akan diangkat menjadi Sultan. Maka Ketua dan para anggota perutusan 
bertolak kembali ke Mekkah dengan seperangkat hadiah, kecuali Syarif Hasyim Jamalullail dan Syarif Ibrahim yang tetap tinggal di Aceh. Utusan yang lainnya sampai di Mekkah pada 14 September $1683 .^{33}$

Selain kedatangan utusan dari Mekkah, Sultanah Zakiatuddin juga kedatangan Utusan Inggris yang datang dari India pada 1684. Utusan Inggris itu bercerita bahwa Sultanah ini suaranya keras dan badannya tegap. Utusan Inggris itu terdiri dari tuan Ord dan Cawley dari Madras yang membawa pesan dari pemerintah Inggris agar diberi izin mendirikan kantor dagang yang diperteguh dengan benteng. Permintaan itu ditolak oleh Sultanah. Disampaikan kepada utusan Inggris bahwa Sultanah sendiri pun tidak akan diizinkan mendirikan benteng di Aceh jika membahayakan kepentingan negara. Memperhatikan butir jawaban tersebut, ada alasan untuk mengatakan bahwa utusan Inggris diterima oleh orang-orang besar, bukan Sultanah. Mereka mengatakan suara Sultanah besar bisa jadi mereka disambut dengan amarah. ${ }^{34}$

Salah seorang pengunjung Inggris lainnya di Aceh masa Sultanah Zakiatuddin yaitu William Dampier. Di

\footnotetext{
${ }^{33}$ A. Hasjmy, Op. Cit., h. 205-208
}

${ }^{34}$ Muhammad Said, Op. Cit., h. 408 dalam bukunya yang banyak dibaca orang, didapat kesan tentang Aceh. Menurutnya, negeri ini diperintah oleh seorang Sultanah, di bawahnya 12 Orang Kaya atau Pangeran Agung. Mereka menjalankan kekuasaannya dalam bidangnya masing-masing dengan hak dan kekuasaan besar. Dan setelah memerintah selama sepuluh tahun, Sultanah Zakiatuddin wafat pada hari Minggu, 3 Oktober $1688 .^{35}$

\section{Masa Sultanah Kamalat Syah Memerintah 1688-1699 M.}

Puteri Kamalat merupakan orang ketiga yang telah dipersiapkan oleh Sultanah Shafiatuddin untuk memimpin pemerintahan Kerajaan Aceh Darussalam. Ia dinobatkan pada hari meninggalnya Sultanah Zakiatuddin, yaitu sebelum upacara pemakaman. Puteri Kamalat menjadi Sultanah dengan gelar Sultanah Sri Ratu Kamalatuddin Inayat Syah. ${ }^{36}$ Wafatnya Sultanah Zakiatuddin dipergunakan sebaikbaiknya oleh sekelompok politisi yang memperalat kaum wujudiyah, peluang telah terbuka bagi mereka merebut kekuasaan. Sekarang tokoh mereka yang akan diajukan menjadi Sultan telah ada, yaitu Syarif Hasyim yang memisahkan

\footnotetext{
${ }^{35}$ A. Hasjmy, Op. Cit., h. 208

${ }^{36}$ Emi Suahimi, Op. Cit., h. 21
} 
diri dari perutusan Syarif Barakat dari Mekkah, apalagi Syarif ini sangat berambisi untuk menjadi Sultan Kerajaan Aceh Darussalam. Dalam kelompok politisi yang memperalat kaum wujudiyah, terdiri dari beberapa orang Uleebalang yang tidak puas selama pemerintahan Sultanah karena ada beberapa hak istimewanya yang telah ditiadakan oleh Sultanah Shafiatuddin dan kemudian dilanjutkan oleh para Sultanah sesudahnya. Itulah sebabnya penobatan Puteri Kamalat menjadi Sultanah menimbulkan perselisihan karena menimbulkan pro dan kontra. Bahkan Puteri Kamalat hampir jatuh dari tahta kerajaan pada masa awal ia dinobatkan. Dengan kebijaksanaan Kadli Malikul Adil, Syekh Abdurrauf Syiah Kuala yang melindungi dan mempertahankannya, serta dukungan penuh yang diberikan oleh Panglima Sagi XXII, XXV, dan XXVI. ${ }^{37}$ Walaupun tantangan Puteri Kamalat cukup berat, namun ia masih sempat memikirkan pembangunan negara dalam berbagai bidang. Kadli Malikul Adil, Syekh Abdurrauf Syiah Kuala, dan para ulama lainnya membantu sepenuhnya.

Kebijaksanaan yang dijalankan Sultanah Zakiatuddin terus dilaksanakan,

${ }^{37}$ A. Hasjmy, Op. Cit., h. 210-211 baik dalam bidang pemerintahan, bidang ekonomi ataupun dalam hubungan luar negeri. Hubungan persahabatan dengan negara-negara tetangga terus dipelihara sementara hubungan dengan Belanda semakin meruncing karena beberapa wilayah Kerajaan di seberang Selat Melaka ataupun di pesisir barat dan timur Sumatera telah digerogoti oleh Persatuan Dagang Belanda (VOC). Pada 1695, berkunjung ke Bandar Aceh Darussalam utusan Persatuan Dagang Inggris yang ingin mendirikan kantor dagang di Aceh. Kedatangan mereka diterima dengan tangan terbuka. Kepada Persatuan Dagang lnggeris itu diperkenankan mendirikan kantornya di Aceh, tetapi Sultanah tidak lalai memikirkan keuntungan yang sebesarbesarnya bagi negara dan rakyat dalam perdagangan dengan Inggris itu. Beberapa peraturan dan perjanjian dibuat Sultanah dengan Persatuan Dagang Inggris (English East India Company) yang semata-mata memberi keuntungan bagi Aceh, sehingga tidaklah seberapa laba yang diperoleh Inggeris dalam perniagaan itu sehingga mereka tidak mendapat kemajuan di sana. ${ }^{38}$

Pada saat Sultanah Kamalat Syah sedang melaksanakan segala rencana pembangunan negara yang telah

${ }^{38}$ Ibid., h. 213-214 
disahkan oleh Balai Majlis Mahkamah Rakyat, tiba-tiba orang kepercayaan sekaligus pendukungnya yang terkuat, yaitu Kadli Malikul Adil Syekh Abdurrauf, meninggal dunia pada malam Senin, 23 Syawal 1106 H/1695 dalam usia 100 tahun lebih. Kadli Malikul Adil pengganti Syekh Abdurrauf tidak cukup kuat menghadapi para penentang yang ingin menjatuhkan Sultanah Kamalat Syah dengan alasan tidak sah perempuan menjadi raja. Bahkan Kadli Malikul Adil yang baru itu, akhimya berpihak kepada golongan penentang dan berangkat ke Mekkah untuk meminta fatwa kepada Mufti Besar Mekkah tentang sah tidaknya perempuan menjadi Kepala Negara, yang segera mengirim surat ke Kerajaan Aceh Darussalam dan menyatakan bahwa perempuan tidak boleh menjadi Sultan.

Menurut llyas Sutan Pamenan dalam buku Rencong Aceh di Tangan Wanita, menyatakan bahwa Kadli Malikul Adil yang telah bergabung dengan golongan para Uleebalang hendak menjatuhkan Sultanah Kamalat, tidak berangkat ke Mekkah tetapi membuat suatu persekongkolan dengan Syarif Hasyim dan Syarif Ibrahim, seakan-akan mereka menerima surat dari Mufti Besar Mekkah bahwa seorang perempuan tidak sah menjadi raja menurut hukum Islam.Akhirnya, Sultanah Kamalat Syah harus turun tahta, yaitu pada 1699. Pada hari itu juga dinobatkan Syarif Hasyim menjadi Sultan Kerajaan Aceh Darussalam dengan gelar Sultan Badrul Alam Syarif Hasyim Jamalullail. Dan berakhirlah pemerintahan para Sultanah dalam sejarah Kerajaan Aceh Darussalam. Tujuh tahun setelah turun tahta, Sultanah Kamalat Syah meninggal dunia pada 1705 dan dimakamkan bersama tiga orang Sultanah sebelumnya di Kandang Dua Belas yang terletak dalam komplek istana Darud Dunia di kota Banda Aceh. $^{39}$

\section{Penutup}

Perjuangan perempuan Aceh bukan hanya sebatas mencari persamaan hak di antara doinasi kaum laki-laki akan tetapi lebih dari itu, mereka memperjuangkan hak-hak manusia untuk merdeka. Pejuang perempuan Aceh yang kemunculannya membentang dari masa ke masa, berjuang untuk membela tanah kelahiran dan bakti kepada Ilahi. Mereka bukan hanya berperan sebagai ibu rumah tangga tetapi juga berjuang di bidang pemerintahan bahkan juga di medan pertempuaran. Perempuan-perempuan Aceh adalah sosok yang kuat, yang

${ }^{39} I b i d$. , h. 215-216 
berjuang dengan semangat jihad fii sabilillah tanpa memperhitungkan harta, tahta, bahkan nyawa mereka.

\section{Daftar Pustaka}

Azra, Azyumardi. 1995. Jaringan Ulama Timur Tengah dan Kepulauan Nusantara Abad XVII-XVIII. Bandung: Mizan.

Djajadiningrat, Raden Hoesein. 1982/1983. Kesultanan Aceh. Daerah Istimewa Aceh: Departemen Pendidikan dan Kebudayaan.

Hadi, Amirul. 2010. Aceh, Sejarah, Budaya, dan Tradisi. Jakarta: Yayasan Obor.

Hamka. 1961. Ummat Islam. Jakarta: Bulan Bintang.

Hasjmy, A. 1977. 59 Tahun Aceh Di Bawah Pemerintahan Ratu. Jakarta: Bulan Bintang.

Jalil, Tuanku Abdul. Tt. Sejarah Singkat Laksamana

Wanita
Keumalahayati. Makalah, PT. Alternati.

Musthafa, Ibnu. 1993. Perempuan Islam Menjelang Tahun 2000. Bandung: Al-Bayan.

Pewara, Adi. 1991. Malahayati Singa Betina Aceh. Surabaya: Karya Anda.

Said, Muhammad. 1981. Aceh Sepanjang Abad, Medan: Waspada.

Salam, Solichin. 1995. Malahayati Srikandi Dari Aceh. Jakarta: Gema Salam.

Suhaemi, Emi. 1993. Wanita Aceh Dalam Pemerintahan Dan Peperangan. Banda Aceh: CV. Gua Hira.

Syariati, Ali. 1985. Fatiah Citra Muslim Sejati. Yogyakarta: Shalahuddin Press.

Zainuddin. 1961. Tarich Atjeh dan Nusantara. Medan: Pustaka Iskandar Muda.

Zainuddin. 1966. Srikandi Atjeh. Medan: Pustaka Iskandar Muda. 